Digital Press Social Sciences and Humanities

Tourist Perception Regarding Orchid Forest As A Digital Tourism Area in West Bandung Regency

Jatmiko Edy Waluyo, Elizabeth Lily, Nisha Shilla and Muhammad Anas Yokasano

Proceeding of Indonesia Heritage Tourism Forum 2019 (IHTF 2019)

Dewi Pratika Ayu Dhira Pradati (eds) 


\title{
Tourist Perception Regarding Orchid Forest As A Digital Tourism Area in West Bandung Regency
}

\author{
Jatmiko Edy Waluyo*, Elizabeth Lily, Nisha Shilla, Muhammad Anas Yokasano \\ Travel Industry Study Program, STP NHI Bandung, Indonesia \\ *e-mail: jae@stp-bandung.ac.id
}

\begin{abstract}
Orchid Forest is a digital tourist area in West Bandung Regency. The Orchid Forest is officially created as a digital destination by the Ministry of Tourism. The inauguration was carried out by Minister of Tourism Arief Yahya. In this case, tourist perception is needed to find out what is the demand of tourists to make Orchid Forest as a digital tourist area in Bandung Regency. So it can provide input for the development of digital tourism, and will attract more tourists to visit. This research is a comparative descriptive study with a quantitative approach based on the results of interviews with area managers and the results of the Annova scale analysis of tourist perceptions consisting of 133 respondents. Based on the results of our study, the existence of gender differences and tourist goals influenced perception.
\end{abstract}

\section{Keywords}

digital tourism, perception, tourists

\section{Introduction}

Tourism is one of the important economic sectors in the West Bandung Regency. The many tourist attractions owned by this region make tourism one of the main destinations to visit this district. according to Suwena \& Widyatmaja (2010) attractions are called a significant component in attracting tourists, attractions are the main capital (tourism resource)/tourism sources. West Bandung Regency itself has several natural tourist destinations that are the center of visitors' arrival, which is Orchid Forest located on Jalan Raya Lembang, Cikole Village, West Bandung Regency. Orchid Forest has officially been used as a digital destination by the Ministry of Tourism. The inauguration was carried out by the former Minister of Tourism Arief Yahya.

In this case, the perception of tourists is needed to find out what is the demand of tourists to make Orchid Forest a digital tourist area in West Bandung Regency. Chaplin (2011) argues that perception is the process of knowing or recognizing objective objects or events that use the senses and awareness of organic processes. So that with the perception of tourists coming to the digital tourist area Orchid Forest can provide input for the development of digital tourism so that it will attract more tourists to visit. And we finally take the title "Tourist Perception Regarding Orchid Forest as a Digital Tourism Area in West Bandung Regency".

\section{Methods}

In conducting research on tourists' perception of the Orchid Forest as a Digital tourism area in West Bandung Regency, researchers used a comparative descriptive method with a quantitative approach. The object of this research is the Orchid Forest area located on Tangkuban Perahu Road KM 8, Cikole, Lembang, West Bandung Regency. The population used in this case were visitors who had visited the tourist area of Orchid Forest, Cikole, West Bandung Regency. In this case, researchers will take a sampling nonprobability technique. The sample used in this case was 133 visitors to the Orchid Forest. In this case, data collection techniques used by researchers were field observations, interviews with the management, and questionnaires. Researchers are used the method of analysis of variance (analysis of variance/ANOVA). 


\section{Finding and Discussion}

In this study, researchers conducted questionnaires to tourists who were visiting and had visited the Orchid Forest Tourism Area as many as 133 respondents. The followings are the results of research that have been processed by researchers from a questionnaire about the perception of tourists regarding Orchid Forest as a digital tourist area in West Bandung Regency.

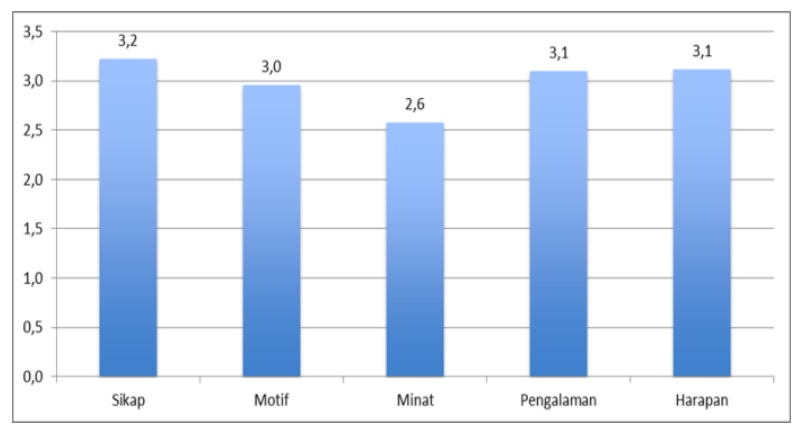

Fig. 1 Tourist perception

Based on the table above, tourists who have a positive attitude towards Orchid Forest means that tourists like some of the tourist attractions provided by Orchid Forest such as the orchid museum, the garden of light, wooden bridge, and rabbit forest. The majority of tourists also agreed that some of the tourist attractions provided by Orchid Forest were very interesting to photograph.

Table 1 Perception Analysis of gender

\begin{tabular}{|c|c|c|c|c|c|c|}
\hline & & Sum of Square & $\mathrm{df}$ & Mean Square & $\mathrm{F}$ & Sig. \\
\hline \multirow[t]{3}{*}{$\overline{\text { Attitude }}$} & Between Group & .550 & 1 & .550 & 3.155 & .078 \\
\hline & Within Group & 22.840 & 131 & .174 & & \\
\hline & Total & 23.390 & 132 & & & \\
\hline \multirow[t]{3}{*}{ Motive } & Between Group & .316 & 1 & .316 & .851 & .358 \\
\hline & Within Group & 48.625 & 131 & .371 & & \\
\hline & Total & 48.941 & 132 & & & \\
\hline \multirow[t]{3}{*}{ Experience } & Between Group & 1.093 & 1 & 1.093 & 4.241 & .041 \\
\hline & Within Group & 33.764 & 131 & .258 & & \\
\hline & Total & 34.857 & 132 & & & \\
\hline \multirow[t]{3}{*}{ Expectation } & Between Group & .245 & 1 & .245 & .861 & .355 \\
\hline & Within Group & 37.216 & 131 & .284 & & \\
\hline & Total & 37.461 & 132 & & & \\
\hline \multirow[t]{3}{*}{ Interest } & Between Group & 3.889 & 1 & 3.889 & 4.874 & .029 \\
\hline & Within Group & 104.532 & 131 & .798 & & \\
\hline & Total & 108.421 & 132 & & & \\
\hline
\end{tabular}

Based on the table above, it shows that men and women have different experiences and interests when visiting Orchid Forest. From the data that we have collected, it shows that men pay more attention to the attractions provided by Orchid Forest, which is less varied, then regarding the motorized parking area and car park which are still not neat and not large and regarding the price of admission which is still relatively expensive. Whereas women are very concerned about the cleanliness of the Orchid Forest, especially the toilets that are still dirty, the less clean water and the location of the toilets are too far away, and the services provided by Orchid Forest are still not good and less friendly to visitors, but both complain of the same access Orchid Forest is very bad with a road that is still hollow, then inside the tourist area there is no adequate shuttle. 
Table 2 Perception analysis of age

\begin{tabular}{|c|c|c|c|c|c|c|}
\hline & & Sum of Square & $\mathrm{df}$ & Mean Square & $\mathrm{F}$ & Sig. \\
\hline \multirow[t]{3}{*}{ Attitude } & Between Group & .799 & 4 & .200 & 1.132 & .344 \\
\hline & Within Group & 22.591 & 128 & .176 & & \\
\hline & Total & 23.390 & 132 & & & \\
\hline \multirow[t]{3}{*}{ Motive } & Between Group & 2.521 & 4 & .630 & 1.738 & .146 \\
\hline & Within Group & 46.420 & 128 & .363 & & \\
\hline & Total & 48.941 & 132 & & & \\
\hline \multirow[t]{3}{*}{ Experience } & Between Group & 1.206 & 4 & .302 & 1.147 & .338 \\
\hline & Within Group & 33.651 & 128 & .263 & & \\
\hline & Total & 34.857 & 132 & & & \\
\hline \multirow[t]{3}{*}{ Expectation } & Between Group & 1.989 & 4 & .497 & 1.795 & .134 \\
\hline & Within Group & 35.471 & 128 & .277 & & \\
\hline & Total & 37.461 & 132 & & & \\
\hline \multirow[t]{3}{*}{ Interest } & Between Group & 3.936 & 4 & .984 & 1.205 & .312 \\
\hline & Within Group & 104.485 & 128 & .816 & & \\
\hline & Total & 108.421 & 132 & & & \\
\hline
\end{tabular}

According to the table above, all the ages of tourists does not affect his perception when visiting the Orchid Forest.

Table 3 Perception analysis of work

\begin{tabular}{|c|c|c|c|c|c|c|}
\hline & & Sum of Square & $\mathrm{df}$ & Mean Square & $\mathrm{F}$ & Sig. \\
\hline \multirow[t]{3}{*}{ Attitude } & Between Group & .011 & 1 & .011 & .062 & .804 \\
\hline & Within Group & 23.379 & 131 & .178 & & \\
\hline & Total & 23.390 & 132 & & & \\
\hline \multirow[t]{3}{*}{ Motive } & Between Group & .110 & 1 & .110 & .294 & .588 \\
\hline & Within Group & 48.831 & 131 & .373 & & \\
\hline & Total & 48.941 & 132 & & & \\
\hline \multirow[t]{3}{*}{ Experience } & Between Group & .445 & 1 & .445 & 1.694 & .195 \\
\hline & Within Group & 34.412 & 131 & .263 & & \\
\hline & Total & 34.857 & 132 & & & \\
\hline \multirow[t]{3}{*}{ Expectation } & Between Group & .297 & 1 & .297 & 1.048 & .308 \\
\hline & Within Group & 37.163 & 131 & .284 & & \\
\hline & Total & 37.461 & 132 & & & \\
\hline \multirow[t]{3}{*}{ Interest } & Between Group & .782 & 1 & .782 & .951 & .331 \\
\hline & Within Group & 107.639 & 131 & .822 & & \\
\hline & Total & 108.421 & 132 & & & \\
\hline
\end{tabular}

Based on the table above, the work does not affect his perception when visiting Orchid Forest. 
Table 4 Perception analysis of origin

\begin{tabular}{|c|c|c|c|c|c|c|}
\hline & & Sum of Square & $\mathrm{df}$ & Mean Square & $\mathrm{F}$ & Sig. \\
\hline \multirow[t]{3}{*}{ Attitude } & Between Group & .050 & 2 & .025 & .138 & .871 \\
\hline & Within Group & 23.341 & 130 & .180 & & \\
\hline & Total & 23.390 & 132 & & & \\
\hline \multirow[t]{3}{*}{ Motive } & Between Group & .291 & 2 & .146 & .389 & .678 \\
\hline & Within Group & 48.649 & 130 & .374 & & \\
\hline & Total & 48.941 & 132 & & & \\
\hline \multirow[t]{3}{*}{ Experience } & Between Group & .301 & 2 & .151 & .567 & .569 \\
\hline & Within Group & 34.55 & 130 & .266 & & \\
\hline & Total & 34.857 & 132 & & & \\
\hline \multirow[t]{3}{*}{ Expectation } & Between Group & .501 & 2 & .251 & .882 & .417 \\
\hline & Within Group & 36.960 & 130 & .284 & & \\
\hline & Total & 37.461 & 132 & & & \\
\hline \multirow[t]{3}{*}{ Interest } & Between Group & .882 & 2 & .441 & .533 & .588 \\
\hline & Within Group & 107.539 & 130 & .827 & & \\
\hline & Total & 108.421 & 132 & & & \\
\hline
\end{tabular}

According to the table above, the area of origin of tourists does not affect its perception when visiting the Orchid Forest.

Table 5 Perception analysis of visits

\begin{tabular}{|c|c|c|c|c|c|c|}
\hline & & Sum of Square & $\mathrm{df}$ & Mean Square & $\mathrm{F}$ & Sig. \\
\hline \multirow[t]{3}{*}{ Attitude } & Between Group & .144 & 3 & .048 & .267 & .849 \\
\hline & Within Group & 23.246 & 129 & .180 & & \\
\hline & Total & 23.390 & 132 & & & \\
\hline \multirow[t]{3}{*}{ Motive } & Between Group & .399 & 3 & .133 & .354 & .787 \\
\hline & Within Group & 48.542 & 129 & .376 & & \\
\hline & Total & 48.941 & 132 & & & \\
\hline \multirow[t]{3}{*}{ Experience } & Between Group & .170 & 3 & .057 & .211 & .889 \\
\hline & Within Group & 34.687 & 129 & .269 & & \\
\hline & Total & 34.857 & 132 & & & \\
\hline \multirow[t]{3}{*}{ Expectation } & Between Group & .129 & 3 & .043 & .148 & .931 \\
\hline & Within Group & 37.332 & 129 & .289 & & \\
\hline & Total & 37.461 & 132 & & & \\
\hline \multirow[t]{3}{*}{ Interest } & Between Group & 1.769 & 3 & .590 & .713 & .546 \\
\hline & Within Group & 106.652 & 129 & .827 & & \\
\hline & Total & 108.421 & 132 & & & \\
\hline
\end{tabular}

The table above shows that how often tourists visit Orchid Forest does not affect their perception of the Orchid Forest. 
Table 6 Perception analysis of income

\begin{tabular}{|c|c|c|c|c|c|c|}
\hline & & Sum of Square & df & Mean Square & $\mathrm{F}$ & Sig. \\
\hline \multirow[t]{3}{*}{ Attitude } & Between Group & .598 & 4 & .149 & .839 & .503 \\
\hline & Within Group & 22.793 & 128 & .178 & & \\
\hline & Total & 23.390 & 132 & & & \\
\hline \multirow[t]{3}{*}{ Motive } & Between Group & 1.680 & 4 & .420 & 1.138 & .342 \\
\hline & Within Group & 47.261 & 128 & .369 & & \\
\hline & Total & 48.941 & 132 & & & \\
\hline \multirow[t]{3}{*}{ Experience } & Between Group & .887 & 4 & .222 & .836 & .505 \\
\hline & Within Group & 33.970 & 128 & .265 & & \\
\hline & Total & 34.857 & 132 & & & \\
\hline \multirow[t]{3}{*}{ Expectation } & Between Group & 1.356 & 4 & .339 & 1.201 & .313 \\
\hline & Within Group & 36.105 & 128 & .282 & & \\
\hline & Total & 37.461 & 132 & & & \\
\hline \multirow[t]{3}{*}{ Interest } & Between Group & .1534 & 4 & .384 & .459 & .765 \\
\hline & Within Group & 106.887 & 128 & .835 & & \\
\hline & Total & 108.421 & 132 & & & \\
\hline
\end{tabular}

The table above shows that income does not affect the perception of tourists visiting the Orchid Forest.

Table 7 Perception analysis of aim

\begin{tabular}{|c|c|c|c|c|c|c|}
\hline & & Sum of Square & $\mathrm{df}$ & Mean Square & $\mathrm{F}$ & Sig. \\
\hline \multirow[t]{3}{*}{ Attitude } & Between Group & 1.365 & 3 & .455 & 2.664 & .051 \\
\hline & Within Group & 22.026 & 129 & .171 & & \\
\hline & Total & 23.390 & 132 & & & \\
\hline \multirow[t]{3}{*}{ Motive } & Between Group & 4.166 & 3 & 1.389 & 4.0001 & .009 \\
\hline & Within Group & 44.775 & 129 & .347 & & \\
\hline & Total & 48.941 & 132 & & & \\
\hline \multirow[t]{3}{*}{ Experience } & Between Group & 3.582 & 3 & 1.194 & 4.926 & .003 \\
\hline & Within Group & 31.274 & 129 & .242 & & \\
\hline & Total & 34.857 & 132 & & & \\
\hline \multirow[t]{3}{*}{ Expectation } & Between Group & 2.557 & 3 & .852 & 3.150 & .027 \\
\hline & Within Group & 34.904 & 129 & .271 & & \\
\hline & Total & 37.461 & 132 & & & \\
\hline \multirow[t]{3}{*}{ Interest } & Between Group & 3.074 & 3 & 1.025 & 1.255 & .293 \\
\hline & Within Group & 105.347 & 129 & .817 & & \\
\hline & Total & 108.421 & 132 & & & \\
\hline
\end{tabular}

Based on the table above, it shows that the destination of tourists coming to Orchid Forest influences their motives, experiences, and hopes in the Orchid Forest. According to the data that researchers have obtained, tourists who come for the purpose of camping pay more attention to access within the Orchid Forest tourist area if the rain will be very slippery and endanger visitors, then tourists who come to take photos pay more attention to the variety of tourist attractions on Orchid Forest, while tourists who come for relaxation pay more attention to the prices of cafes in the Orchid Forest tourist area and the supporting facilities such as seating and places for relaxation. 


\section{Conclusion}

According to the analysis of perceptions of the sex of tourists, there is a difference in the perceptions of experience and interest between male and female tourists, the majority of male tourists pay more attention to tourist attractions, parking areas, and ticket prices, while female tourists pay more attention to cleanliness especially toilet cleanliness and service. But as many as 126 respondents from both men and women will upload photos or videos on Orchid Forest to the social media they have.

In addition, the results of the analysis of perceptions of tourist destinations also showed differences in motives, experiences, and expectations for tourists with the aim of camping, photographs, or relaxation. For tourists aiming for camping, 3 out of 4 tourists choose not to upload their photos on social media, and they pay attention to the facilities provided by Orchid Forest for camping and the price of facilities for camping is also quite expensive, but for tourists with the aim of taking pictures and relaxation, the majority will upload their photos on social media and they pay more attention to the prices of cafes located in the Orchid Forest.

The criteria of age, occupation, area of origin, frequency of visits, and tourist income do not affect the perception of tourists visiting the Orchid Forest. For future research, researchers are expected to be able to conduct further research on the Orchid Forest.

Based on the results of this study, there are several things that researchers recommend, including:

a) As input for management of the tourist area of Orchid Forest to pay more attention to the cleanliness of tourist attractions, especially in the case of toilets on weekends and increase the trash can.

b) Regarding the facilities that have been provided by Orchid Forest, such as motorbike and car parking lots can be renewed, adding to the number of toilets, making a place to shelter, and increase lighting within the Orchid Forest tourist area.

c) Many tourists who have visited the Orchid Forest are bored with tourist attractions that are not renewed or added to other tourist attractions, this can be an input for Orchid Forest to renew existing tourist attractions or add new tourist attractions.

\section{References}

Chaplin, J. P. (2011). Kamus Lengkap Psikologi. Jakarta: Rajawali Pers.

Suwena, I. K., \& Widyatmaja, I. G. (2010). Pengetahuan Dasar Ilmu Pariwisata. Denpasar: Udayana University Press. 